\title{
Usefulness of Septodermoplasty in Hereditary Hemorrhagic Telangiectasia
}

\author{
Chan Joo Yang, Bong-Jae Lee, and Yong Ju Jang \\ Department of Otolaryngology, Asan Medical Center, University of Ulsan College of Medicine, Seoul, Korea
}

\author{
유전성 출혈성 모세혈관 확장증에 의한 비출혈 환자에서 비중격식피술의 유용성 \\ 양찬주 - 이봉재 - 장용주 \\ 울산대학교 의과대학 서울아산병원 이비인후과학교실
}

\author{
Received June 16, 2014 \\ Revised August 18, 2014 \\ Accepted August 31, 2014 \\ Address for correspondence \\ Yong Ju Jang, MD, PhD \\ Department of Otolaryngology, \\ Asan Medical Center, \\ University of Ulsan \\ College of Medicine, \\ 88 Olymphic-ro 43-gil, \\ Songpa-gu, Seoul \\ 138-736, Korea \\ Tel $+82-2-3010-3710$ \\ Fax $+82-2-489-2773$ \\ E-mail jangyj@amc.seoul.kr
}

Background and Objectives Epistaxis is the most common symptom in patients with hereditary hemorrhagic telangiectasia (HHT). The aim of this study is to report treatment of severe epistaxis related to HHT with the septodermoplasty and to assess patient outcomes.

Subjects and Method Six patients with HHT who underwent septodermoplasty from 2009 to 2013 were reviewed retrospectively. We analyzed the clinical characteristics, surgical management and treatment outcomes.

Results Three patients had been diagnosed with definite HHT and three patients with possible HHT. Three patients had combined abnormal vascular structures in visceral organs. The mean preoperative and postoperative hemoglobin were $7.2 \mathrm{~g} / \mathrm{dL}$ and $12.8 \mathrm{~g} / \mathrm{dL}$, respectively, and visual analogue scale score for frequency and intensity of nasal bleeding remarkably decreased after septodermoplasty in all patients.

Conclusion Septodermoplasty was a safe and efficacious procedure for reducing the frequency and severity of bleeding in most patients with intractable epistaxis and HHT.

Korean J Otorhinolaryngol-Head Neck Surg 2015;58(5):330-6

Key Words Epistaxis · Hereditary hemorrhagic telangiectasia.

\section{서 론}

유전성 출혈성 모세혈관 확장증(hereditary hemorrhagic telangiectasia)은 Osler-Rendu-Weber 증후군이라고 불리는 상염색체 우성 유전에 따른 질환으로 모세혈관 확장 및 동정 맥 기형을 특징으로 나타낸다.,2) 유전성 출혈성 모세혈관 확 장증에서는 혈액 조성 이상이나 혈액응고 장애 없이 혈관 성장 의 문제로 혈관벽이 깨지기 쉬워 사소한 자극에도 출혈이 발 생하게 되고, ${ }^{3}$ 혈관벽의 탄력 섬유 부족으로 혈관 수축이 일어 나지 않아 쉽게 지혈이 되지 않는다. ${ }^{4)}$ 이러한 혈관 이상은 비 점막에서 가장 흔하게 발견되며 비강의 공기 흐름과 같은 약한 자극에도 쉽게 출혈을 일으키게 되어 전체 환자들 중 약 90 $96 \%$ 에서 반복적인 비출혈을 보인다. ${ }^{5-7)}$ 이러한 혈관 이상이 주
요한 내장 기관에도 발생하게 되고 뇌나 폐 등의 주요장기에 위치한 동정맥 기형 또는 동맥류로 인해 저산소증과 같은 호 흡기 장애 또는 신경학적 후유증과 같은 심각한 합병증이 발 생할 수 있으나 ${ }^{7)}$ 환자가 병원을 방문하게 되는 주된 이유는 잦 은 비출혈이기 때문에 이비인후과 의사는 유전성 출혈성 모 세혈관 확장증의 조기 진단과 치료에 중요한 역할을 한다. 외국 문헌에 의하면 유전성 출혈성 모세혈관 확장증에 기인한 반복 적인 비출혈의 치료로 다양한 방법들이 시도되고 있으나 영구 적으로 출혈을 막을 수 있는 치료 방법은 없는 것으로 보이며 주로 비출혈의 빈도와 정도를 감소시키는 데에 목적을 두고 있다. ${ }^{8-12)}$ 에스트로겐 등을 사용한 약물치료와 레이저 소작술 등의 수술적 치료들이 시도되고 있는데 그 중에서도 비중격식 피술의 성적이 좋은 것으로 알려져 있다. ${ }^{2,9,12-14)}$ 국내에서도 비 
중격식피술로 치료한 증례가 보고된 바 있으나 모두 1 예의 단독 보고였으며 치료의 한 방법으로 비중격식피술을 제시하였을 뿐 여러 환자의 치료 결과를 비교 분석한 보고는 없었다. $3,15-17)$ 따라서 본 연구에서는 본원에서 유전성 출혈성 모세혈관 확장 증을 진단받고 비중격식피술을 시행 받은 6예의 치료 결과를 분석해 보고자 한다.

\section{대상 및 방법}

2009년 4월부터 2013년 3월까지 본원에서 유전성 출혈성 모세혈관 확장증을 진단받고 비중격식피술을 시행 받은 6명의 환자를 대상으로 후향적으로 의무 기록을 분석하였다.

\section{진 단}

Curacao 진단기준에 따라 가능성이 낮은 군(unlikely group) 의 환자를 제외한 확정군(definite group) 또는 의심군(possible group)에 해당하는 경우를 유전성 출혈성 모세혈관 확장증으 로 진단하였다(Table 1). ${ }^{18)}$ 수술 전후 비출혈의 강도와 빈도에 대해서 visual analogue scale(VAS) 방식으로 조사하였다. 0점 은 불편한 점이 전혀 없는 상태, 10 점은 증상이 심해 일상 생 활 및 건강상에 매우 심각한 영향을 받는 상태인 경우로 설명 하여 환자가 느끼는 주관적인 증상의 정도를 점수로 내도록 하였다.

\section{수술적 기법}

모든 수술은 전신마취 하에 시행되었다. $1 \%$ 의 리도카인과 1:100000 에피네프린을 양측 비강에 주사하였고 6명의 환자 중 3명에서는 좋은 수술 시야 확보를 위해 외측 비익 절개 접

Table 1. The Curacao Criteria

\begin{tabular}{|c|c|}
\hline Criteria & \\
\hline 1. Epistaxis & Spontaneous, recurrent nose bleeds \\
\hline 2. Telangiectases & $\begin{array}{l}\text { Multiple, at characteristic sites: } \\
\text { lips, oral cavity, fingers, nose }\end{array}$ \\
\hline \multirow[t]{6}{*}{ 3. Visceral lesions } & Such as \\
\hline & $\begin{array}{l}\text { Gastrointestinal telangiectasia } \\
\text { (with or without bleeding) }\end{array}$ \\
\hline & Pulmonary AVM \\
\hline & Hepatic AVM \\
\hline & Cerebral AVM \\
\hline & Spinal AVM \\
\hline 4. Family history & $\begin{array}{l}\text { A first-degree relative with } \mathrm{HHT} \\
\text { according to these criteria }\end{array}$ \\
\hline
\end{tabular}

Hereditary hemorrhagic telangiectasia diagnosis is considered definite if three criteria are present, possible or suspected if two criteria are present and unlikely if fewer than two criteria are present. AVM: arteriovenous malformation, HHT: hereditary hemorrhagic telangiectasia 근법(lateral alotomy approach)을 이용하였다(Fig. 1A). 출 혈성 경향을 보이는 비중격의 점막과 하비갑개, 중비갑개의 점막을 큐렛(curet) 또는 회전식 흡입기(microdebrider)를 이용 하여 제거하였으며 특히 비중격의 점막을 제거할 때에는 가능 한 많은 점막성 연골막(mucoperichondrium)을 보존하면서 점막 을 제거할 수 있도록 주의하였다(Fig. 1B). Zimmer air dermatome (Zimmer Surgica Inc., Warsaw, IN, USA)을 이용하여 외측 허벅지에서 약 $9 \times 15 \mathrm{~cm}$ 크기의 피부를 채취하였다(Fig. 1C). 2 명의 환자에서는 채취한 피부를 실라스틱 시트에 미리 부착 하여 비중격 부위에 적용하고 고정하는 방식을 통해 수술 시 간을 절약하고 이식 피부의 위치 이탈을 방지할 수 있었다 (Fig. 1D). 점막이 제거된 비중격, 하비갑개, 중비갑개, 그리고 비저부에 채취된 피부를 이식하였다(Fig. $1 \mathrm{E}$ and F).

\section{결 과}

총 6명의 환자 중 Curacao 진단 기준에 따라 3 명의 환자는 확정 군(definite group), 3 명의 환자는 의심 군(possible group) 에 해당되었다. 남자가 4 명, 여자가 2 명이었으며 평균 나이는 55.3세(50 61세)였다. 6명의 환자 모두 술전 매일 비출혈이 발생하였었고 평균적으로 5 10분 후 지혈되었으나 심한 경우 는 응급실 진료 및 수혈이 필요한 경우도 있었다. 증상의 기간 은 5년에서 40년까지 다양하게 나타났으며 공통적으로 전기 소작술을 반복적으로 시행 받았다. 2 명의 환자에서는 레이저 소작술을 시행 받았으나 호전이 없었다(Table 2).

신체 검사상 4명의 환자에서 비점막뿐만 아니라 입술, 구강, 손가락 등에 모세혈관 확장증 소견을 보였다. 1 명의 환자는 대장 내시경검사에서 대장 혈관이상(intestinal telangiectasia) 이 발견되었고 또 다른 1명의 환자에서는 뇌동맥류(brain aneurysm)로 뇌동맥류 색전술을 시행한 과거력, 또 다른 1명의 환자에서는 폐동정맥 기형으로 수술을 받았던 과거력이 있었 다. 하지만 이외 3 명의 환자에서는 수술 전 시행한 검사 상 위 장관계, 호흡기계, 그리고 뇌신경계의 혈관 이형성 등의 문제 는 발견되지 않았거나 관련된 검사를 시행하지 않았다. 모든 환자에서 명확한 유전성 출혈성 모세혈관 확장증의 가족력은 없었다(Table 2).

수술 후 평균 경과 관찰 기간은 19.8개월(12 31개월)이었다. 수술 전 평균 혈색소 수치는 $7.2 \mathrm{~g} / \mathrm{dL}$ 였고 수술 후 평균 혈색 소 수치는 $12.8 \mathrm{~g} / \mathrm{dL}$ 였다. Case 4 환자에서 비출혈 강도 및 빈 도에 대한 술후 VAS score는 술전의 1/9 수준으로 감소하며 비중격식피술 후 21개월 째 시행한 혈색소 수치가 $15 \mathrm{~g} / \mathrm{dL}$ 로 수술 전 $4.6 \mathrm{~g} / \mathrm{dL}$ 에 비해서 현저한 호전 소견을 보였다(Table 3).

비중격식피술을 계획하였을 당시 비중격 천공이 관찰되었던 
3 명의 환자 중 2 명은 수술 후 비중격 천공이 다시 발생하였으 며 이 중 Case 3 환자에서는 수술 후에도 비출혈이 반복적으 로 발생해 재수술 및 혈관 조영술을 이용하여 지혈을 시행하였 다(Table 2 and 3 ).

대표적인 환자 3 명을 자세히 살펴보도록 하겠다.

\section{Case 1}

기저질환 없이 건강하던 53세 남자 환자가 5년 전부터 반복 되는 비출혈 및 빈혈을 주소로 본원 이비인후과 외래 내원하 였다. 환자는 1 년 전 반복되는 비출혈의 원인으로 비중격만곡 증 진단 하에 비중격교정술을 시행받았으나 이후에도 비출혈
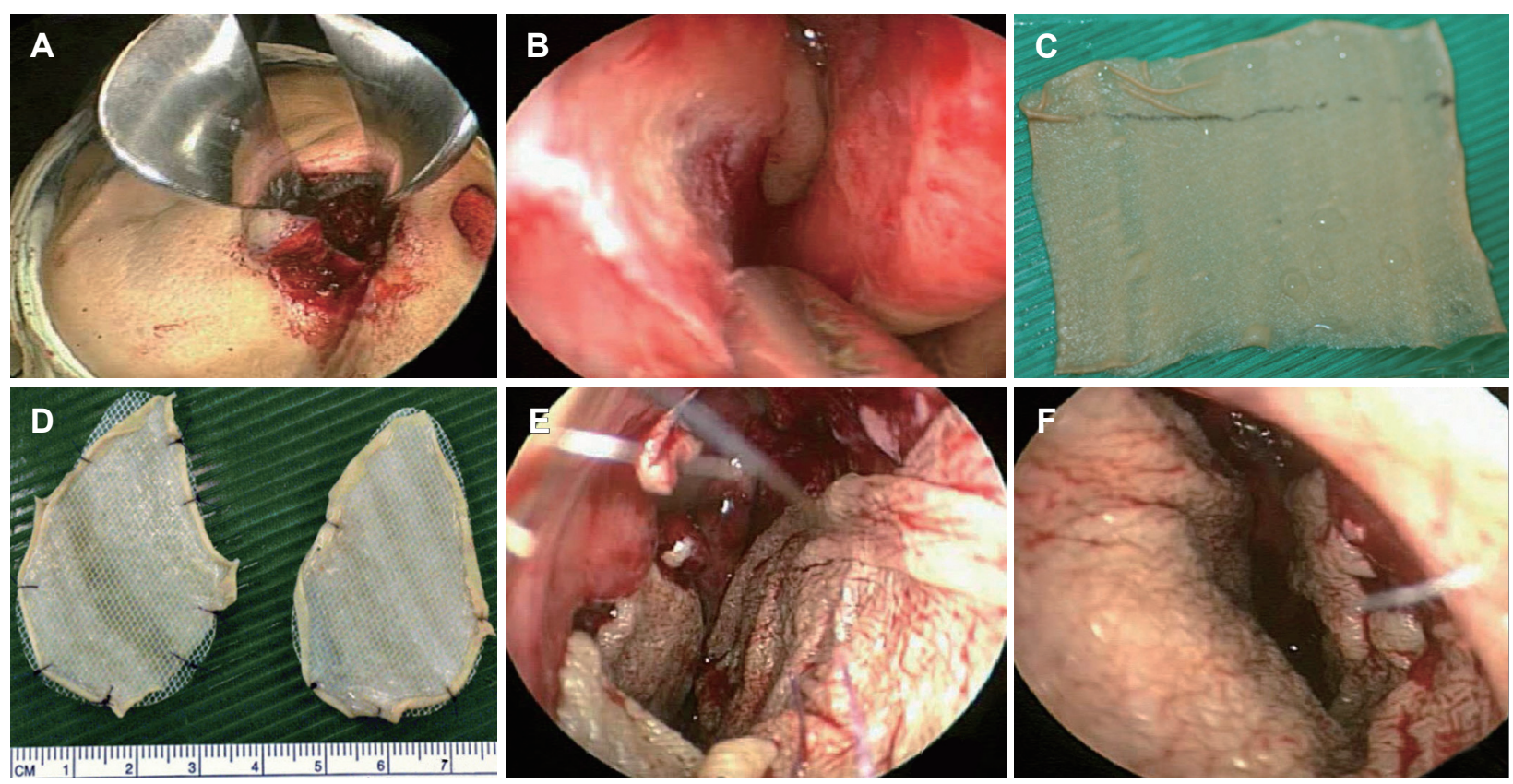

Fig. 1. Intraoperative view of septodermoplasty. Lateral alotomy incision was done (A). Inferior turbinate mucosa and septal mucosa was removed with shaver (B). A split-thickness skin graft of $9 \times 15 \mathrm{~cm}$ size was harvested from lateral thigh with a dermatome (C). Harvested skin graft was stitched with silastic sheet (D). The graft was placed into the nasal cavity along the septum, around the floor of the nose, and onto the denuded areas of the lateral nasal wall ( $\mathrm{E}$ and $\mathrm{F})$.

Table 2. Patients characteristics and clinical manifestation

\begin{tabular}{|c|c|c|c|c|c|c|c|}
\hline $\begin{array}{l}\text { Case } \\
\text { No. }\end{array}$ & $\begin{array}{l}\text { Sex/age } \\
\text { (years) }\end{array}$ & Diagnosis* & Nasal cavity exam & Other lesions & $\begin{array}{l}\text { Family } \\
\text { history }\end{array}$ & $\begin{array}{l}\text { Duration of } \\
\text { epistaxis } \\
\text { (years) }\end{array}$ & $\begin{array}{l}\text { Treatment of epistaxis } \\
\text { before septodermoplasty }\end{array}$ \\
\hline 1 & $M / 50$ & $P$ & $\begin{array}{l}\text { Hemorrhagic } \\
\text { telangiectasia } \\
\text { Absent septal } \\
\text { cartilage }\end{array}$ & $\begin{array}{l}\text { Telangiectases at lip } \\
\text { and fingers }\end{array}$ & None & 5 & $\begin{array}{l}\text { Transfusion } \\
\text { Electrocauterization } \\
\text { Septoplasty }\end{array}$ \\
\hline 2 & $F / 53$ & $D$ & $\begin{array}{l}\text { Hemorrhagic } \\
\text { telangiectasia }\end{array}$ & $\begin{array}{l}\text { Telangiectases at } \\
\text { tongue } \\
\text { Brain aneurysm }\end{array}$ & None & 20 & $\begin{array}{l}\text { Transfusion } \\
\text { Electrocauterization } \\
\text { Laser cauterization } \\
\text { Septoplasty }\end{array}$ \\
\hline 3 & $F / 61$ & $D$ & $\begin{array}{l}\text { Hemorrhagic } \\
\text { telangiectasia } \\
\text { Septal perforation }\end{array}$ & $\begin{array}{l}\text { Telangiectases at lip, } \\
\text { toes, and fingers } \\
\text { Pulmonary AVM }\end{array}$ & None & 15 & $\begin{array}{l}\text { Transfusion } \\
\text { Electrocauterization }\end{array}$ \\
\hline 4 & $M / 58$ & $D$ & $\begin{array}{l}\text { Hemorrhagic } \\
\text { telangiectasia } \\
\text { Septal perforation }\end{array}$ & $\begin{array}{l}\text { Intestinal } \\
\quad \text { telangiectasia } \\
\text { (without bleeding) }\end{array}$ & None & 40 & $\begin{array}{l}\text { Transfusion } \\
\text { Electrocauterization } \\
\text { Laser cauterization }\end{array}$ \\
\hline 5 & $M / 50$ & $P$ & $\begin{array}{l}\text { Hemorrhagic } \\
\text { telangiectasia } \\
\text { Septal perforation }\end{array}$ & $\begin{array}{l}\text { Telangiectases at } \\
\text { tongue }\end{array}$ & None & 20 & $\begin{array}{l}\text { Electrocauterization } \\
\text { Septoplasty } \\
\text { Septal perforation repair }\end{array}$ \\
\hline 6 & $M / 60$ & $\mathrm{P}$ & $\begin{array}{l}\text { Hemorrhagic } \\
\text { telangiectasia }\end{array}$ & None & None & 30 & $\begin{array}{l}\text { Transfusion } \\
\text { Electrocauterization }\end{array}$ \\
\hline
\end{tabular}

* diagnosis according to the Curacao Criteria. M: male, F: female, P: possible hereditary hemorrhagic telangiectasia, D: definite hereditary hemorrhagic telangiectasia, AVM: arteriovenous malformation 
이 반복되어 본원에 내원하여 비강 내 출혈성 모세혈관 확장 소견이 관찰되어(Fig. 2A) 유전성 출혈성 모세혈관 확장증 진단 하에 비중격식피술을 계획하였다. 환자에서 비강 외에도 입술, 손가락 끝에 모세혈관 확장 소견이 관찰되었으며 본원에 서 시행한 흉부 전산화단층촬영 및 뇌 자기공명영상 검사 상 에서 뇌 또는 폐의 동정맥 기형은 발견되지 않았다. 내원 당시 혈색소 농도가 $4.4 \mathrm{~g} / \mathrm{dL}$ 로 확인되어 혈액내과에서 수혈 및 철 분제를 복용하여 혈색소 $11.4 \mathrm{~g} / \mathrm{dL}$ 까지 회복 후 수술을 진행 하였으며 수술 후 혈색소 농도 검사는 시행하지 않았다. 시야 확보를 위해 외측 비익 절개 접근법을 시행하였으며 출혈성 혈
관이 관찰되는 비중격, 비저부, 하비갑개, 중비갑개의 점막을 회전식 흡입기를 이용하여 제거하였다. 환자는 비중격 연골이 존재하지 않는 상태였으며 채취해 놓은 허벅지 피부를 이용하 여 제거된 점막표면에 피부이식을 하고 수술을 종료하였다. 수 술 후 2년 간 외래를 통해 경과 관찰하였으며 수술 후 비중격 천공의 합병증이 발생하였으나 코피의 빈도 및 강도는 수술 전 VAS score 각각 10, 4에서 0으로 현저하게 줄었다(Fig. 2B).

\section{Case 2}

20여 년 전 뇌동맥류로 수술 받았던 과거력이 있는 55세

Fig. 2. Nasal endoscopic findings of case 1. Preoperative nasal endoscopic finding: telangiectases of nasal cavity (A). Postoperative nasal endoscopic finding: septal perforation (B).

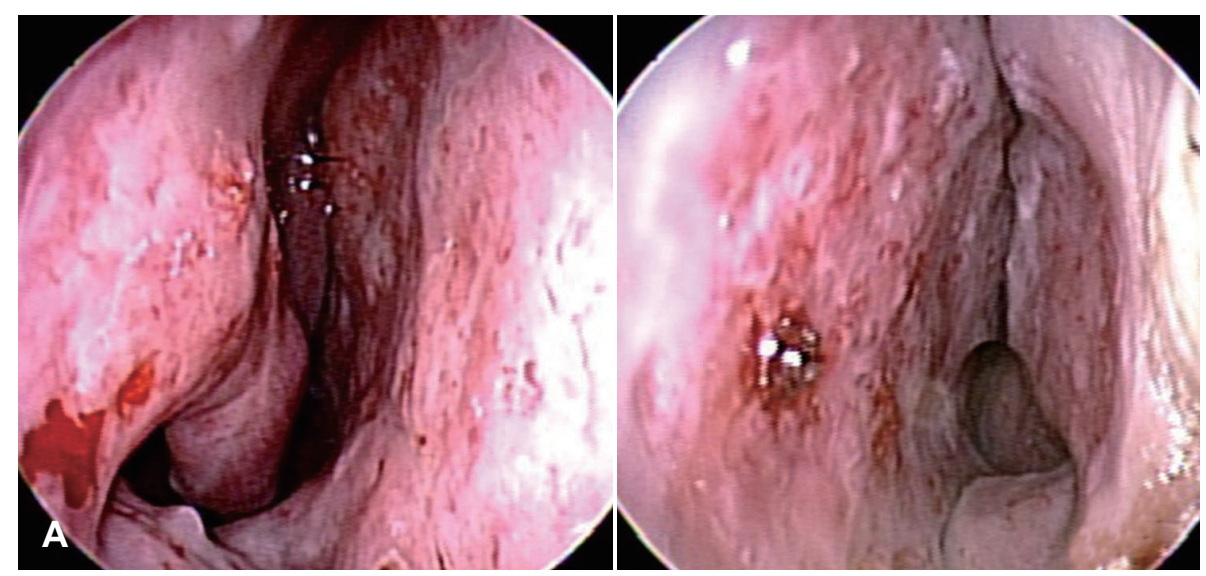

Table 3. Result of septodermoplasty

\begin{tabular}{|c|c|c|c|c|c|c|c|c|}
\hline \multirow[t]{2}{*}{$\begin{array}{l}\text { Case } \\
\text { No. }\end{array}$} & \multirow{2}{*}{$\begin{array}{c}\text { Postoperative } \\
\text { follow up duration } \\
\text { (months) }\end{array}$} & \multirow[t]{2}{*}{$\begin{array}{c}\text { Postoperative } \\
\text { nasal cavity exam }\end{array}$} & \multicolumn{2}{|c|}{$\begin{array}{c}\text { Frequency of } \\
\text { epistaxis } \\
\text { (VAS score) }\end{array}$} & \multicolumn{2}{|c|}{$\begin{array}{c}\text { Intensity of epistaxis } \\
\text { (VAS score) }\end{array}$} & \multicolumn{2}{|c|}{$\begin{array}{l}\text { Hemoglobin } \\
\text { (g/dL) }\end{array}$} \\
\hline & & & Preop & Postop & Preop & Postop & Preop & Postop \\
\hline 1 & 24 & Septal perforation & 10 & 0 & 4 & 0 & 4.4 & - \\
\hline 2 & 31 & Intact nasal cavity mucosa & 10 & 1 & 10 & 1 & 5 & 11.1 \\
\hline 3 & 12 & Septal perforation & 10 & 5 & 10 & 6 & 4.2 & 6.1 \\
\hline 4 & 21 & Septal mucosa defect & 9 & 1 & 9 & 1 & 4.6 & 15 \\
\hline 5 & 14 & Septal perforation & 10 & 3 & 10 & 4 & 14.3 & 15.9 \\
\hline 6 & 17 & Intact nasal cavity mucosa & 9 & 1 & 9 & 1 & 10.8 & 15.1 \\
\hline
\end{tabular}

VAS: visual anglogue scale, Preop: preoperative, Postop: postoperative 
여자 환자가 반복되는 비출혈로 본원 내원하였다. 비출혈의 발 생 원인으로 비중격만곡증 진단 하에 2007년 비중격교정술, 2008년 레이저 소작술을 받았으나 증상이 지속되고 비강내 출
혈성 모세혈관 확장 소견 및 비중격 천공이 관찰되어(Fig. 3A) 유전성 출혈성 모세혈관 확장증 진단 하에 2009년 비중격식피 술을 시행하였다. 수술 31 개월 후 코피의 빈도 및 정도가 모두

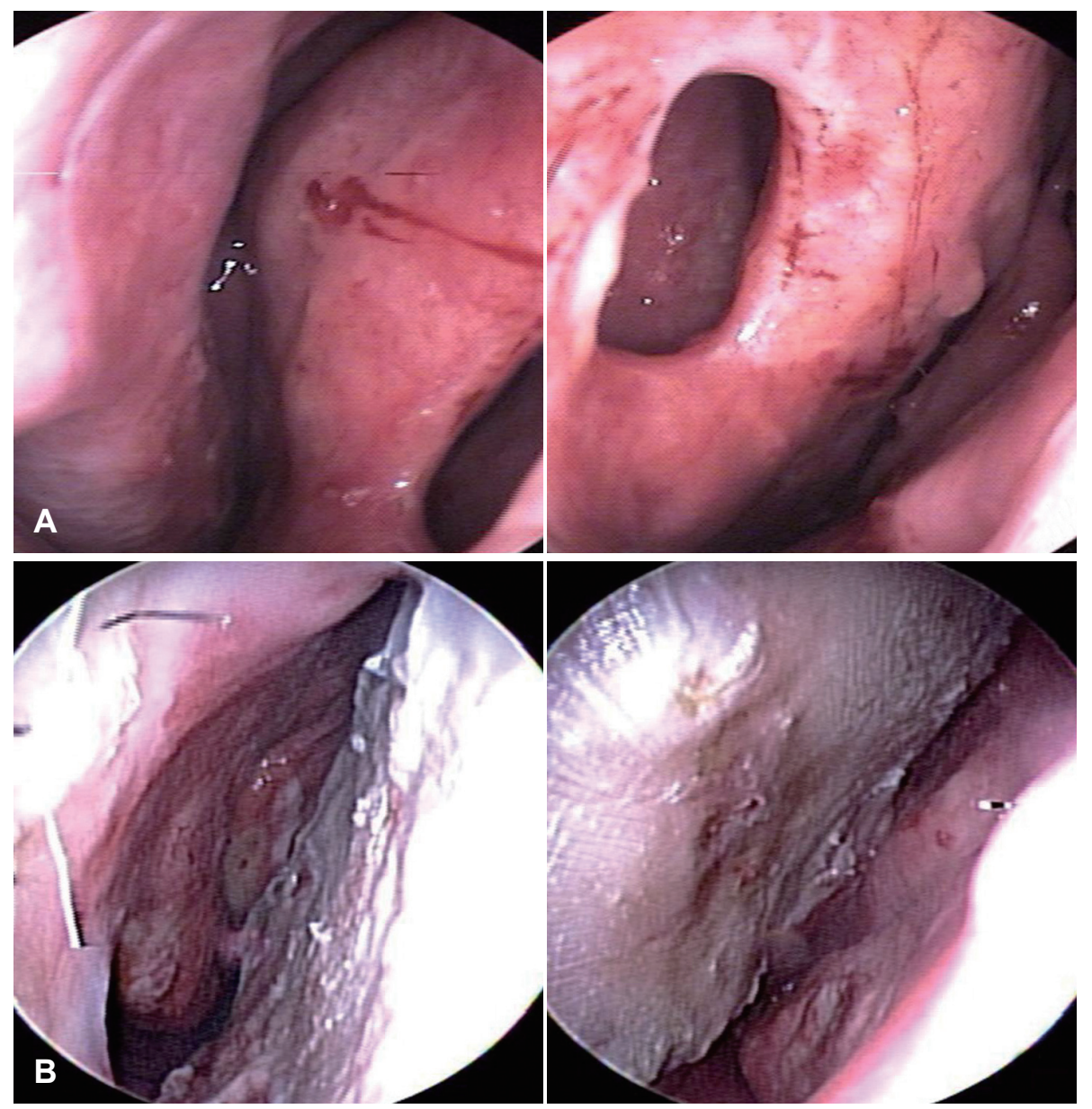

Fig. 3. Nasal endoscopic findings of case 2. Preoperative nasal endoscopic finding: telangiectases of nasal cavity and septal perforation (A). Postoperative nasal endoscopic finding: intact skin graft placed into the nasal cavity along the septum (B).
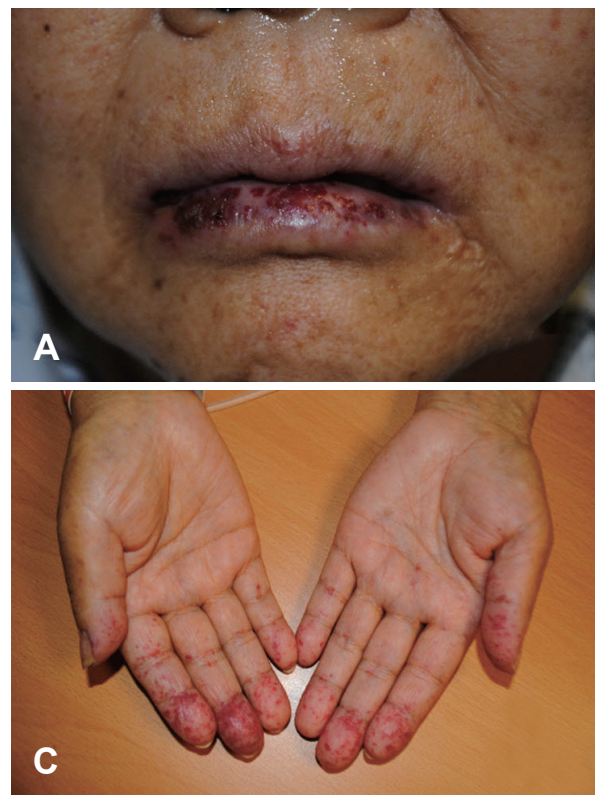
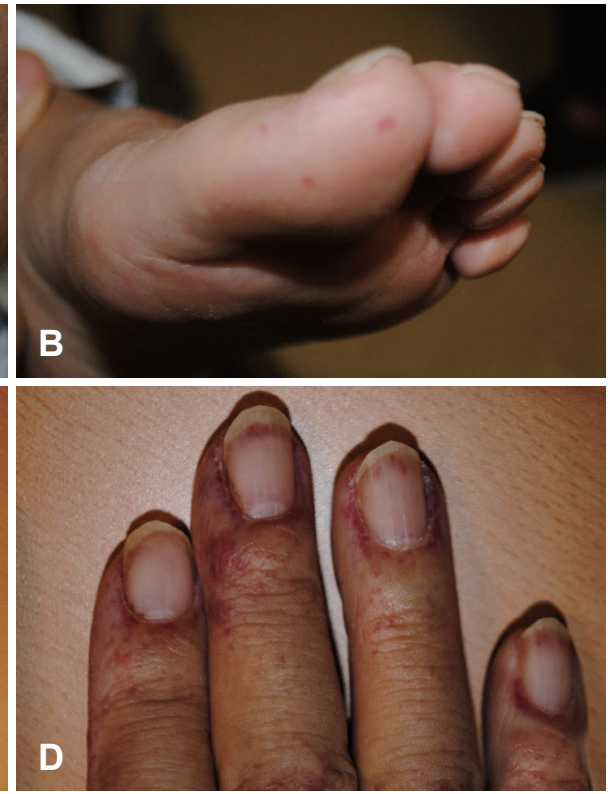

Fig. 4. Telangiectases of case 3 . Telangiectases of lip (A). Telangiectases of toes (B). Telangiectases of fingers $(C$ and $D)$. 
수술 전 VAS score 10에서 1로 감소하였으며 비강 내시경 소 견 상 이식 피부의 생착이 문제없이 이루어지며 출혈 소견이 관찰되지 않았다(Fig. 3B).

\section{Case 3}

61세 여자 환자가 15년 전부터 반복되는 비출혈을 주소로 본원 외래에 내원하였다. 환자는 10여 년 전 폐동정맥 기형으 로 타원에서 수술을 받았던 기왕력이 있으며 7여 년 전 반복 되는 비출혈로 본원 내원하였으나 당시에는 비특이적 비출혈 진단하에 전기 소작술 및 수혈을 받았다. 이후 타병원에서 유 전성 출혈성 모세혈관 확장증을 진단 받고 경과 관찰 하던 중 전기 소작술 및 3 4회/년의 반복적인 수혈 치료에도 불구하고 지속되는 비출혈 및 빈혈을 주소로 비중격식피술을 시행 받기 위해 본원 외래로 내원하였다. 외래 내원하였을 당시 입술, 손 끝, 발 끝에도 모세혈관 확장 소견을 보였고(Fig. 4) 비중격 천 공 주변으로 심각한 출혈 소견을 보이며 혈색소 수치가 $4.2 \mathrm{~g} /$ $\mathrm{dL}$ 로 확인되었다. 응급 수혈 후 혈색소 농도 $9.8 \mathrm{~g} / \mathrm{dL}$ 로 회복 후 비중격식피술을 시행하였다. 비중격 천공 재건술은 시행 하지 않았으며 출혈 경향을 보이는 비중격, 하비갑개, 중비갑 개, 비저부 전반의 점막을 회전식 흡입기를 통해 제거한 후 허 벅지에서 채취한 피부를 이식하였다. 수술 전 시행한 부비동 전산화단층촬영상 우측 상악동 내 만성 부비동염 소견을 보 여 우측 중비도 상악동 개방술을 함께 시행하였다. 수술 후 코피의 빈도 및 정도가 모두 수술 전 VAS score 10에서 1로 감소하였으나 수술 후 1 개월 경 다시 비출혈이 발생하여 입원 하여 전신마취 하에 전기 소작을 시행하였다. 수술 소견 상 비 강 측벽의 이식 피부에서는 출혈 소견이 보이지 않았으나 양측 중비갑개의 점막에서 지속적인 출혈 소견이 보여 양측 중비 갑개 절제술을 시행하였다. 수술 후 3 개월 경 비출혈이 발생하 여 전신마취 하에 전기 소작술을 시행하였으나 지혈되지 않아 두경부 혈관 조영술을 통해 내상악동맥 및 얼굴동맥의 색전술 로 지혈하였다. 수술 후 12 개월간 외래 통한 경과 관찰 중으로 코피의 빈도 및 정도가 VAS score 5, 6으로 다시 증가하였으 며 수술 후 12 개월 경 마지막으로 시행한 혈색소 수치는 $6.1 \mathrm{~g} /$ $\mathrm{dL}$ 로 확인되었다.

\section{고 찰}

유전성 출혈성 모세혈관 확장증은 보고자에 따라서는 재 발성 비출혈, 피부 또는 점막의 모세혈관 확장증 및 가족력의 세 조건을 충족할 때 진단하기도 하나 ${ }^{19,20)}$ 본 연구에서는 재발 성 비출혈, 점막 또는 피부의 모세혈관 확장증, 내부 위장관계 의 동정맥 기형 및 가족력의 4 가지 조건 중 2 가지 이상인 경우
를 유전성 출혈성 모세혈관 확장증으로 진단하였다. ${ }^{2)}$

모세혈관 확장증은 구강 점막(58 79\%), 얼굴(30 63\%)에서 도 관찰되나 비점막(68 100\%)에서 가장 흔하게 발견된다. ${ }^{21)}$ 본 연구에 포함된 환자 6 명 중에서 4 명의 환자에서는 비강 점 막 외에도 입술, 구강, 손가락 등에 모세혈관 확장증이 관찰되 었다. 이 이상 혈관들은 약한 자극에도 쉽게 출혈을 일으키게 되는데, 본 연구의 모든 환자에서 반복적인 비출혈과 빈혈 소견을 보이고 있었다.

유전성 출혈성 모세혈관 확장증의 치료 목표는 혈관 이상 부 위의 출혈을 방지하여 출혈의 빈도와 정도를 감소시키고, 출 혈에 의한 2차적인 합병증을 조절 또는 예방하는 것이다. 비출 혈에 대한 치료로 국소압박법, 비패킹, 전기 소작술, 동맥 색전 술, 비중격식피술, 에스트로겐 요법, 레이저 치료, 국소 또는 유 리피판 등 현재까지 다양한 방법이 제안되었다..$^{8-10,12,13,20)}$ 일반적 으로 급성기에는 국소압박법, 비패킹 및 전기 소작술 등이 사 용되나 이는 출혈을 악화시킬 수 있으며 장기적인 치료법이 되 지는 못하며, 동맥 결찰이나 색전술은 출혈이 심할 경우에 시 도 할 수 있는 방법들이다.2) 약물 치료로는 에스트로겐 경구 치료가 시도되고 있으나 여러 가지 부작용으로 인하여 심한 재 발성 출혈에서 제한적으로 사용하고 있다. ${ }^{23,24}$ 최근 들어 레이저 치료법과 비중격식피술 1325$)$ 이 주로 많이 사용되고 있는데, 비출 혈 초기에 자주 시행 되었던 레이저 치료법은 $2 \mathrm{~mm}$ 이상의 병 변의 경우에는 레이저에 반응하여 출혈이 더 유발될 수 있고, ${ }^{9}$ 여러 차례의 수술을 요하는 경우가 많으며, 레이저에 의한 외 상의 위험성이 있고 급성기에는 비교적 성적이 좋으나 장기간 성공률이 낮은 것으로 보고되고 있다.1) 비중격식피술은 현재 까지 알려진 유전성 출혈성 모세혈관 확장증 환자의 비출혈 치 료법 중 가장 좋은 방법으로 되어 있으며, 성공률을 65 80\% 까지 보고하는 이들도 있다. ${ }^{2,13)}$ 비중격식피술에서는 모세혈 관 확장증 소견을 보이는 이상 비점막의 대부분을 제거하고 편 평 상피로 이루어진 두터운 피부를 점막에 이식하게 되는데, 비정상 혈관이 분포하는 이상 점막과는 달리 이식 피부는 외 상을 잘 견디어 출혈을 줄일 수 있다. ${ }^{13)}$ 그러나 일부 저자들은 이 술식이 일시적인 증상의 개선을 보이지만 이식된 면적이 불충분하여 이차적인 이식물의 수축으로 병변이 다시 노출되 거나, 새롭게 증식되는 모세혈관들이 이식 편을 관통하여 모 세혈관 확장증이 재발되는 경우 비중격식피술이 실패하게 된 다고 보고하였다. ${ }^{26)}$

국내에서 유전성 출혈성 모세혈관 확장증 환자에서 비중 격식피술을 시행한 증례 보고가 있었으나 비출혈의 치료 방 법의 하나로 제시하였을 뿐 본 연구에서와 같이 VAS score로 환자의 주관적인 증상 변화에 대하여 비교 평가하고 혈색소 수치의 변화로 객관적인 치료 효과를 평가한 보고는 없었다. 
이 연구에서 보고한 6명의 환자에서 모두 수술 후 출혈의 빈도와 정도가 감소하였고 객관적인 혈색소 수치도 수술 후 호전되었음을 알 수 있었으나 Case 3 환자를 살펴본 결과, 수술 직후 출혈 빈도, 정도가 현저하게 호전된 소견을 보였다가 반복되는 비출혈로 전기소작술을 시행한 후 다시 출혈 빈도, 정도가 증가하는 소견을 보였다. 이 환자의 경우 초기 진단이 늦어지며 수술 전 비중격 천공이 있었던 환자로 수술 후 비중 격 천공과 반복적인 비출혈이 있어 시행한 재수술로 인해 이식 한 점막이 모두 제거되며 이상혈관이 새롭게 증식되며 다시 증 상 악화를 유발한 것으로 고려된다. 보고한 6명의 환자 중 Case 3 환자를 포함하여 3 명의 환자에서 수술 전 비중격 천공이 존 재하였는데 이러한 환자의 경우 수술적 기법에 있어서 어려움 이 있었고 이 중 2 명의 환자에서는 수술 후 비중격 천공의 지속 또는 재발하며 치료 결과도 좋지 않음을 알 수 있었다. 초기 진 단이 늦어질수록 반복적인 전기적 소작술로 인해 비중격 천공 이 발생할 수 있으며 이러한 환자의 경우 치료가 어렵기 때문 에 초기 진단이 중요함을 알 수 있다.

비록 적은 증례이기는 하나 본 연구를 통해 유전성 출혈성 모세혈관 확장증에 의해 2차적으로 발생한 비출혈의 치료에 있어 비중격식피술이 효과적임을 알 수 있었다. 그러나 6명의 수술장 소견을 살펴보면 비중격식피술의 기술적인 한계를 알 수 있었는데, 허벅지에서 채취한 피부가 비중격 전장 또는 비강 의 측벽 점막까지 모두를 덮지는 못 하면서 이식 피부의 상피 화가 정상적으로 일어난 부위에서는 출혈이 없었으나 이식 피 부의 경계 부위에서는 출혈이 지속되는 것을 관찰하였다. 또한 수술 후 이식 피부가 생착되는 과정에서 가피 형성 및 점액 생 성 등으로 인해 환자들은 코에서 나는 악취로 힘들어 함을 알 수 있었다. 비록 환자에 따라 비중격식피술의 기술적인 한계가 있었지만 본 연구를 통해 6명의 환자에서 모두 수술 후 비출혈 이 빈도 및 강도가 줄어듦을 알 수 있었다. 유전성 출혈성 모 세혈관 확장증에 의한 비출혈의 치료로 아직까지 뚜렷한 효과 를 보이는 다른 치료법이 없기 때문에 현 시점에서는 조기에 유 전성 출혈성 모세혈관 확장증을 진단하고 비중격식피술을 시행 하는 것이 최선의 치료법이라 할 수 있다.

\section{REFERENCES}

1) Byahatti SV, Rebeiz EE, Shapshay SM. Hereditary hemorrhagic telangiectasia: what the otolaryngologist should know. Am J Rhinol 1997;11(1):55-62.

2) Guttmacher AE, Marchuk DA, White RI Jr. Hereditary hemorrhagic telangiectasia. N Engl J Med 1995;333(14):918-24.

3) Lee $\mathrm{CH}$, Yoo YS, Park WW. A case of hereditary hemorrhagic telangiectasia (HHT). Korean J Otolaryngol-Head Neck Surg 1990;33 (1):185-91.

4) Govani FS, Shovlin CL. Hereditary haemorrhagic telangiectasia: a clinical and scientific review. Eur J Hum Genet 2009;17(7):860-71.

5) Haitjema T, Disch F, Overtoom TT, Westermann CJ, Lammers JW.
Screening family members of patients with hereditary hemorrhagic telangiectasia. Am J Med 1995;99(5):519-24.

6) Reilly PJ, Nostrant TT. Clinical manifestations of hereditary hemorrhagic telangiectasia. Am J Gastroenterol 1984;79(5):363-7.

7) Sadick H, Sadick M, Götte K, Naim R, Riedel F, Bran G, et al. Hereditary hemorrhagic telangiectasia: an update on clinical manifestations and diagnostic measures. Wien Klin Wochenschr 2006;118(3-4):72-80.

8) Lund VJ, Howard DJ. A treatment algorithm for the management of epistaxis in hereditary hemorrhagic telangiectasia. Am J Rhinol 1999;13 (4):319-22.

9) Harvey RJ, Kanagalingam J, Lund VJ. The impact of septodermoplasty and potassium-titanyl-phosphate (KTP) laser therapy in the treatment of hereditary hemorrhagic telangiectasia-related epistaxis. Am J Rhinol 2008;22(2):182-7.

10) Yaniv E, Preis M, Shevro J, Nageris B, Hadar T. Anti-estrogen therapy for hereditary hemorrhagic telangiectasia - a long-term clinical trial. Rhinology 2011;49(2):214-6.

11) Rimmer J, Lund VJ. A modified technique for septodermoplasty in hereditary hemorrhagic telangiectasia. Laryngoscope 2014;124 (1):67-9.

12) Geisthoff UW, Fiorella ML, Fiorella R. Treatment of recurrent epistaxis in HHT. Curr Pharm Des 2006;12(10):1237-42.

13) Saunders WH. Septal dermoplasty for hereditary telangiectasia and other conditions. Otolaryngol Clin North Am 1973;6(3):745-55.

14) Fiorella ML, Ross D, Henderson KJ, White RI Jr. Outcome of septal dermoplasty in patients with hereditary hemorrhagic telangiectasia. Laryngoscope 2005;115(2):301-5.

15) Chung SK, Moon IH. A case of hereditary hemorrhagic telangiectasia. Korean J Otolaryngol-Head Neck Surg 1994;37(1):157-61.

16) Kim SS, Yoo SY, Kim MS, Choi YS. A case of hereditary hemorrhagic telangiectasia: surgical treatment with modified septodermoplasty. Korean J Otolaryngol-Head Neck Surg 1999;42(2):245-8.

17) Mun SJ, Yoo YT, Cho SW, Lee JE, Han DH, Min YG, et al. Clinical characteristics and comorbidities of hereditary hemorrhagic telangiectasia. Korean J Otorhinolaryngol-Head Neck Surg 2012;55 (4):222-8.

18) Shovlin CL, Guttmacher AE, Buscarini E, Faughnan ME, Hyland RH, Westermann CJ, et al. Diagnostic criteria for hereditary hemorrhagic telangiectasia (Rendu-Osler-Weber syndrome). Am J Med Genet 2000; 91(1):66-7.

19) McCaffrey TV, Kern EB, Lake CF. Management of epistaxis in hereditary hemorrhagic telangiectasia. Review of 80 cases. Arch Otolaryngol 1977;103(11):627-30.

20) Saunders WH. Hereditary hemorrhagic telangiectasia, its familial pattern, clinical characteristics, and surgical treatment. Arch Otolaryngol 1962;76:245-60.

21) Haitjema T, Westermann CJ, Overtoom TT, Timmer R, Disch F, Mauser $\mathrm{H}$, et al. Hereditary hemorrhagic telangiectasia (Osler-WeberRendu disease): new insights in pathogenesis, complications, and treatment. Arch Intern Med 1996;156(7):714-9.

22) Weissman JL, Jungreis CA, Johnson JT. Therapeutic embolization for control of epistaxis in a patient with hereditary hemorrhagic telangiectasia. Am J Otolaryngol 1995;16(2):138-40.

23) Flessa HC, Glueck HI. Hereditary hemorrhagic telangiectasia (OslerWeber-Rendu disease). Management of epistaxis in nine patients using systemic hormone therapy. Arch Otolaryngol 1977;103(3):148-51.

24) Harrison DF. Hereditary haemorrhagic telangiectasia and oral contraceptives. Lancet 1970;1(7649):721.

25) Bridger GP. Hereditary hemorrhagic telangiectasia. A new dermoplasty technique. Arch Otolaryngol Head Neck Surg 1992;118(9):992-3.

26) Levine CG, Ross DA, Henderson KJ, Leder SB, White RI Jr. Long-term complications of septal dermoplasty in patients with hereditary hemorrhagic telangiectasia. Otolaryngol Head Neck Surg 2008;138 (6):721-4. 